\title{
EVALUATING EXTINCTION IN RARE HABITATS: AN ESSAY
}

\author{
A. I. Camacho* and A. G. Valdecasas*
}

\begin{abstract}
Inference and estimation are the Achilles heel of many biological disciplines. The validation of results is the first step before taking any further decision. In Biodiversity studies the technical problems in validation are similar to those faced in other disciplines. The main difference with areas like medicine is that a validation error in the latter can easily take you to court, but very few responsibilities apart from moral or ethical ones generally derive from a faulty estimation or validation in Biodiversity.

However, many political decisions concerning conservation issues, which in many cases affect powerful economic interests depend on the reliability of those biodiversity studies. Getting good, reliable information is not always easy, and this explains in part, the success of critical voices like Simon (1998) and Lomborg (2001). New methodologies like Population Viability Analysis has been developed to take advantage of the potential information contained in periodical sampling. We apply it to a peculiar and difficult to study fauna: the fauna of the aquatic subterranean environment. Lack of regular information and scarcity of the fauna due to difficulty to reach their proper habitat are the main problems that confront this analysis. However, despite its limitations, the analysis points towards a need to better understand the structure of the subterranean habitat from "an animal point of view" and the need of more regular sampling at the same time that the other environmental parameters are taken.
\end{abstract}

Key words: aquatic subterranean domain, extinction risk, PVA, bathynelids, Iberian Peninsula.

\section{RESUMEN}

\section{Ensayo sobre la evaluación de la extinción en hábitats extremos}

La inferencia y la estima son el talón de Aquiles de muchas disciplinas biológicas. La validación de resultados es el primer paso antes de tomar decisiones ulteriores. En estudios de Biodiversidad los problemas técnicos de validación son semejantes a los que se enfrentan otras disciplinas. La principal diferencia con áreas como Medicina es que un error en validación en ésta última puede terminar fácilmente en el juzgado, pero muy pocas responsabilidades, aparte de la éticas o morales suelen afectar a estimas o validaciones defectuosas de Biodiversidad.

Sin embargo, muchas decisiones políticas en relación a la conservación de especies y habitats, que en muchos casos implican poderosos intereses económicos, dependen precisamente de la fiabilidad de los estudios de biodiversidad. Obtener una información buena y fiable no es siempre fácil y explica, en parte, el éxito de voces críticas como Simon (1998) o Lomborg (2001). En este trabajo revisamos uno de los problemas de estimación en un habitat especialmente difícil, el medio subterráneo acuático. La carencia de información periódica y la escasez de esta fauna, debido principalmente a las dificultades de acceso a su habitat, son los principales problemas que hemos encontrado al tratar de aplicar análisis PVA (Populations Viability Analysis). No obstante, a pesar de la escasez de datos consistentes, este análisis pone de manifiesto la necesidad de entender mejor la estructura del habitat subterráneo, en lo que respecta a la distribución de su fauna y la necesidad de realizar más muestreos y de realizarlos con mayor regularidad.

Palabras clave: medio acuático subterráneo, riesgo de extinción, PVA, batinelas, Península Ibérica.

* Museo Nacional Ciencias Naturales. Departamento de Biodiversidad y Biologia Evolutiva. Jose Gutiérrez Abascal 2. 28006MADRID 


\section{Introduction}

Knowledge is marred by uncertainty. How much we need to know in order to be almost certain about something or simply dubious about it depends very often on personal conviction. Methods have been developed using statistical theory to limit these degrees of uncertainty but even these depend on assuming starting points and other premises that we are not one hundred per cent sure of.

This is also true in biological disciplines that can affect economic and political decisions. Estimation of species richness or species extinction are delicate issues when dealing with environmental planning and development projects. Both issues fall within the now common Biodiversity ambit. Critics like Simon (1998) or Lomborg (2001) have a dual role to play in this area, which in some sense should be welcomed. First, they help to make "Headlines" of really important problems. Knowing how much biodiversity we are losing annually is not a trivial matter. Of course, some biologists would assert that Simon and Lomborg's estimation is too optimistic. While other biologists are too pessimistic. This is not an issue with a precise answer, or a middle point. The answer is uncertain, but this does not necessarily imply a lack of knowledge. We know, but we lack proper figures.

In this regard we should learn from the trivial appropriation of the modern philosophy of science for which many scientists are to blame. Where are the "propositions" to falsify, when all we are dealing with is "uncertainty"? Should we throw away all the available evidence and related facts because they can not be built into a neatly quantitatively argued hypothesis?

Short answers are sometimes the best rebuttals, and may be it is not necessary to go beyond the concise review of Lomborg's book given by Pimm and Harvey (2001) in Nature and to agree that in terms of Biodiversity we are working with those "unnamed millions we infer". We would only add that in the case of those we know, too frequently we know too little.

Subterranean aquatic fauna clearly illustrate these points: how difficult it is to establish reasonable ranges in an estimation while at the same time having a certain amount but spatially sparse data.

THE AQUATIC SUBTERRANEAN FAUNA OF THE IBERIAN PENINSULA

When dealing with the aquatic subterranean fauna, one is confronted with a similar situation to that which Corbet and Williams presented to Fisher
(Fisher, Corbet and Williams, 1943): in any biotic collection rare species are plentiful and abundant species are scarce. At the same time we know that according to simple biological principles, populations should have a minimum size, if a species is to survive. The explanation to this conundrum in the case of subterranean fauna is the certainty that very often we are only allowed to sample peripheral populations or peripheral habitat realms.

Aquatic subterranean fauna are very difficult to sample mainly for two reasons: first, the subterranean environment is very difficult to access for the prospective sampler. Second, and possibly a corollary of the first, the distribution and defined habitat of their populations is not known with any great certainty.

This subterranean aquatic environment extends throughout consolidated sediments, mainly in karstic areas, and in unconsolidated sediments below the bottom of rivers, what is being called the hyporheic environment by the specialists. This hyporheic milieu is phreatic water extending beyond the banks of rivers and the confined aquifers, only accessible via wells. The special thing about the karstic subterranean environment is their three-dimensional extension through galleries, passages, fissures and crevices of different sizes and extentions. Accessibility to this habitat is variable. The only part of their environment to which man can gain access is what is traditionally called the cave, which is not always easy (some of them are more than 1 $\mathrm{km}$ deep). Habitats found in caves are gours, small ponds and medium sized lakes, subterranean rivers, interstitial water under sandy banks, sumps, springs and sources. However, an important part of this three-dimensional habitat is barely accessible to our sampling efforts: the crevices, where an important amount of water and organic material enter this subterranean domain. It is a reasonable assumption that most aquatic subterranean fauna live there. For what we usually find in the caves is only a small part of those populations that have been carried away by high waters or by passive or active distribution by or against gravity. In this way they end up where we can sample them.

Bearing this in mind it is no surprise that up to the fifties of the last century only a few mites and crustaceans were known in the aquatic subterranean environment of the Iberian Peninsula. And this due to the meritorious efforts researchers like Racovitza, 1907, Braga, 1949 and Margalef, 1951, 1953.

Things have changed substantially since them, and more than 500 species have been found, although not all are strictly subterranean. Very often, 
more commonly than in epigeous habitats, species are represented by single specimens. And this leads to the reasonable assumption that we are not sampling where they really live, for if this were the case, extinction would be their certain fate. But they are found again and again, always in very low numbers.

In this work we deal with Bathynellacea (Crustacean, Syncarida), a group that one of us (A. C.) has been studying for almost 20 years.

Forty six species of Bathynellacea are known on the Iberian Peninsula and the Balearic Islands in more than 160 localities, one fourth of the species in the world, 205. Some species still remain to be described.

\section{Material and methods}

We have reviewed 330 populations in 166 localities including 41 species. These populations are distributed on the Iberian Peninsula and the island of Mallorca. A total of 141 populations come from caves (55 different caves), 8 from springs ( 8 different springs), 30 from wells (26 well localities) and 151 from the interstitial river environment (77 rivers).

The following species for which a census exist for ten or more years have been selected: Iberobathynella cantabriensis Camacho \& Serban, 1998, I. imuniensis Camacho, 1987, Paraiberobathynella fagei (Delamare Deboutteville \& Angelier, 1950) and Hexaiberobathynella mateusi (Galhano, 1967). Census here is taken to mean the taking of one or several samples in a year in a definite karstic area. Their abundance over the duration of the census are shown in Fig. 1.

Population Viability Analysis (PVA) "refers to the use of quantitative methods to predict the likely future status of a population" (Morris et al 1999). There are several ways of doing it. We chose the option that best suited our data.

The following assumptions were used in the application of the method:

1) The sampling area for each species, except $P i$. fagei is defined by natural karstic regions, were continuity and communication between caves and basins is known or can reasonably be assumed. Pi. fagei is distributed over a large part of the Iberian Peninsula, taken here as its natural area, mainly for exploratory purposes.

2) A census is the total number of samples taken during a natural year.
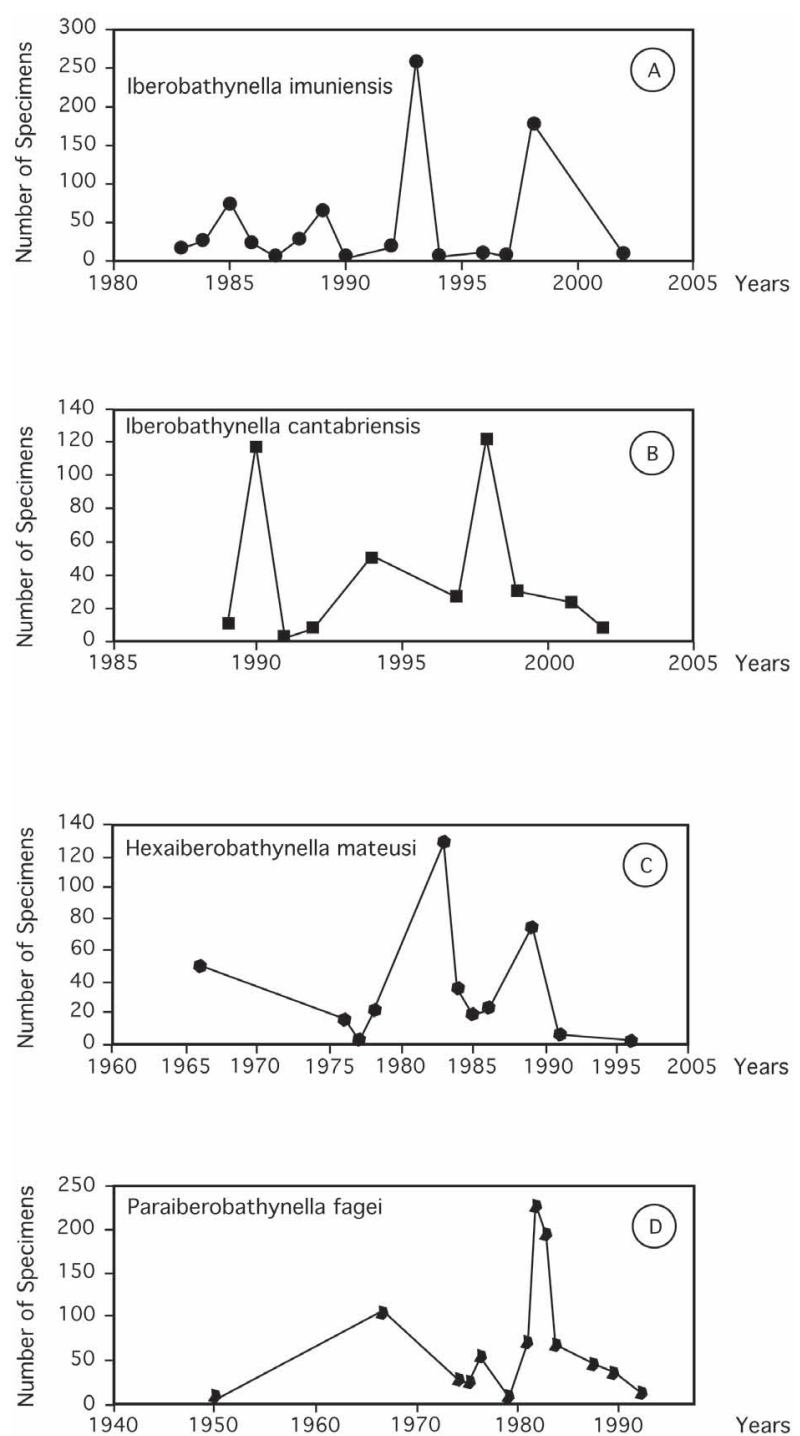

Fig. 1.- Count data for: a) Iberobathynella cantabriensis Camacho and Serban, 1998 (Distribution area: Lamasón); b) I. imuniensis Camacho, 1987 (Distribution area: Ason, Lamasón, Burgos \& Huesca); c) Paraiberobathynella fagei (Delamare \& Angelier, 1950) (Distribution area: Iberian Peninsula \& Balearic Island) and d) Hexaiberobathynella mateusi (Galhano, 1967) (Distribution area: Central Spain).

Fig. 1.- Recuento para: a) Iberobathynella cantabriensis Camacho and Serban, 1998 (área de distribución: Lamasón); b) I. imuniensis Camacho, 1987 (área de distribución: Ason, Lamasón, Burgos \& Huesca); c) Paraiberobathynella fagei (Delamare \& Angelier, 1950) (área de distribución: Iberian Peninsula \& Balearic Island) and d) Hexaiberobathynella mateusi (Galhano, 1967) (área de distribución: Central Spain). 
3) Total number of males, females and juveniles make up the figures included in the analysis.

4) The PVA method used is count-based extinction analysis in a minimum of ten years.

Due to the nature of the data and the analysis, the present work should be viewed more as a tentative assessment of risk of extinction rather than a certain prediction of the fate of a population.

The detailed methodology followed can be consulted in Morris et al. 1999. Further assumptions of PVA will be treated in the discussion.

\section{Results and Discussion}

PVA analysis are based on the estimation of mean $(\mu)$ and standard deviation $\left(\sigma^{2}\right)$ for each species based on a series of counts. With the data available and following the methodology of Morris et al. (1999) we arrived at the following statistic values for the four species presented in Table 1 .

a) The mean and standard deviation of each species obtained through regression analysis.

b) The average population growth rate $\lambda$.

c) The mean time to extinction, calculated as the time necessary for the decline from the actual number of specimens to the extinction threshold assumed valid for the species, and

d) The cumulative distribution function for the conditional time to extinction (Fig. 2) where several statistics like median time to extinction or the probability of extinction at certain date can be calculated.

Only the statistics concerning Pi. fagei seem comparable with values found for other species in the ecological literature, and these give an extinction risk of 10.8 years. We know that this is surely not the case. Values for other average population growth rates are not to be trusted ranging from a similar extinction risk for $\mathrm{Hi}$. mateusi of about ten years up to 70 years for imuniensis. All these estimations depend on the figure taken as threshold for extinction as well as the figure taken for the actual population size. Both of them are in our four cases laden with uncertainty.

The basic problem resides in the $\mu$ and $\sigma^{2}$ estimation by regression. Of the four assumptions implicit in this method (Dennis et al. 1991 in Morris et al. 1999) the main caveat pertaining to our data is assumption (b) which assumes that the "year per year variation in the counts reflects the true magnitude of environmentally-driven variation."

In our species, the year per year variation must reflect more the animal distribution and the sampling effort in the subterranean environment and less abundance or intrinsic population properties.

Sampling carried out in areas accessible to researchers could provide representative numbers of animals in wet years, when all the subterranean "spaces" have been interconnected by water flow. Dry years facilitate isolation and the sampling becomes no longer representative. The moral is: the same places are not equivalent for the species in different years.

In this sense, the subterranean aquatic environment is peculiar and different from other aquatic habitats. Ponds, lakes and rivers remain were they are, and, if we exclude temporary ponds, their populations remain in their physical space.

The aquatic subterranean environment has a transient nature, due to annual and seasonal water variations. During wet years and at the peak of the rainy season, some caves could be full of water or whole tracks could be flooded. In this period, most of the

Table 1.- Diffusion model PVA statistical parameters for the four species of bathynelids.

Tabla 1.- Parámetros estadísticos del modelo de difusión PVA para cuatro especies de batinelas.

\begin{tabular}{lcccc}
\hline Species & $\mathbf{X}$ & $\sigma^{2}$ & $\lambda$ & Mean Time to extinction \\
\hline I. imuniensis & -0.033 & 6.641 & 26.7 & 67.7 \\
I. cantabriensis & $8.5 \times 10^{-18}$ & 4.020 & 7.464 & $5.50 \times 10^{16}$ \\
Pi. fagei & -0.130 & 2.677 & 3.347 & 10.6 \\
Hi. mateusi & -0.081 & 0.921 & 1.461 & 10.8 \\
\hline
\end{tabular}



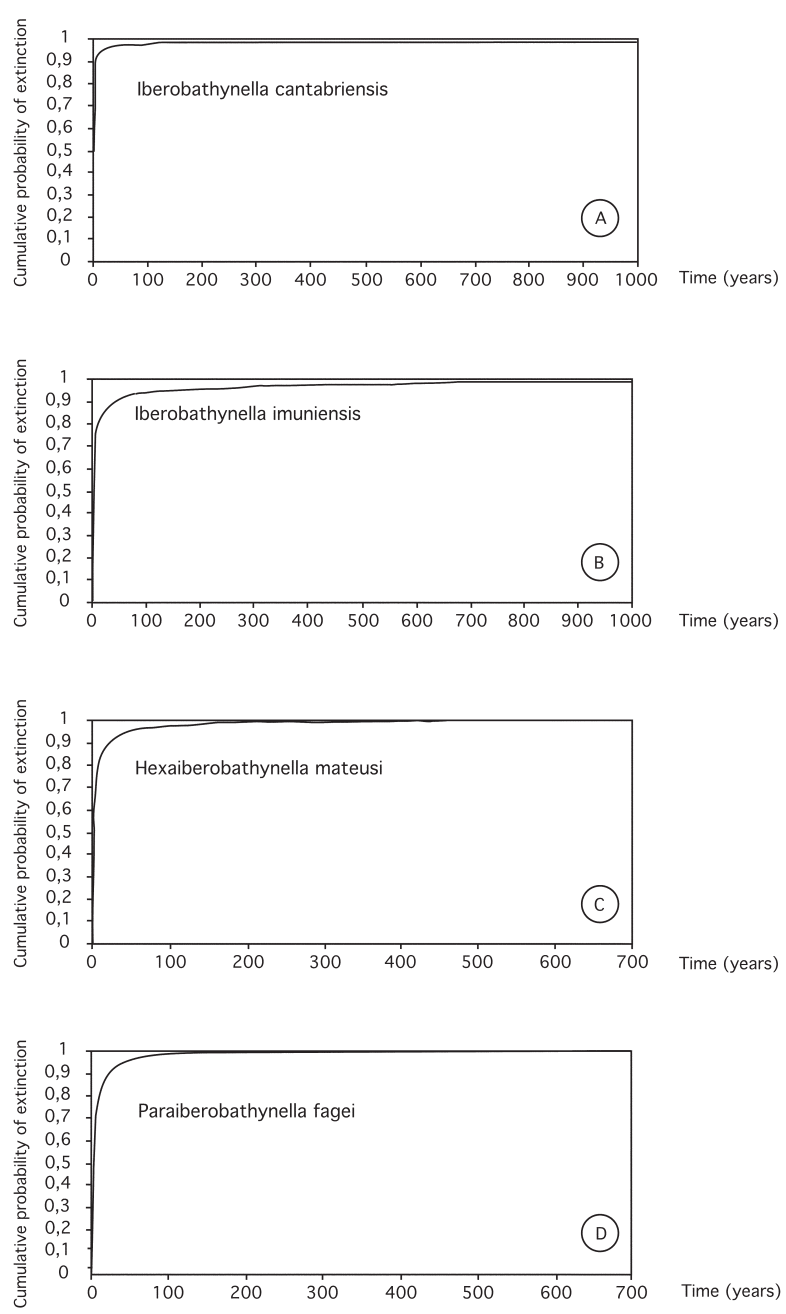

Fig. 2.- Cumulative distribution function of extinction time for: a) Iberobathynella cantabriensis Camacho and Serban, 1998; b) I. imuniensis Camacho, 1987; c) Paraiberobathynella fagei (Delamare y Angelier, 1950) and d) Hexaiberobathynella mateusi (Galhano, 1967).

Fig. 2.-Distribución de la probabilidad acumulativa del tiempo de extinción para: a) Iberobathynella cantabriensis Camacho and Serban, 1998; b) I. imuniensis Camacho, 1987; c) Paraiberobathynella fagei (Delamare y Angelier, 1950) and d) Hexaiberobathynella mateusi (Galhano, 1967).

subterranean domain is a "continuum". In dry years or seasons, water retreats, evaporates in many places and what is left could be found where local conditions allow it to endure, but obviously, not always in the same place. Besides, it is known through laboratory experimentation that many subterranean taxa, bathynelids included, cease reproduction in dry years, waiting for more favourable times which bring water enriched with organic matter.

Paradoxically enough, the reason why statistics for Pi. fagei estimation seems nearer to a true census, is because its sampling area was the biggest, the whole of the Iberian Peninsula considered as a single connected environment.

It can be concluded that the nature of the data do not fit properly with the assumptions of the model. Scattered sampling, although done at regular intervals do not built a proper census specially I the case of organisms whose distribution is highly affected by one or two environmental variables, in our case, precipitation. When water is scarce, the space where the animals retreat is not available with the actual sample gears. So it is more correct to say that these data can not be fed into PVA model to give a probability of extinction. They provide a clue of rarity, the likelihood that with an equivalent sampling they will become sufficiently rare and will not be detected.

\section{Conclusions}

It has not been our purpose to criticize the use of the PVA method on census data, but to provide a practical example that clearly shows why for some animal groups or environments the quantitative estimation of either their diversity or protection needs is especially difficult. New methods are needed that could give a more realistic estimation of the basic statistical parameters, before embarking on a more quantitative evaluation.

This is not to say that this data is worthless from a conservation point of view. Despite the inadequacy of the data for this quantitative analysis, it gives us an approximate picture of the populations living in the subterranean environment.

So, it is certain that there is some room for Simpson and Lomborg criticisms but only if we adhere to a very formal definition of what should be considered to be reasonably known. Qualitative and semi-quantitative work has a potential to delineate in general terms a characterization of biodiversity and extinction risk that has a basis in truth and deprive these critics of ultimate wisdom.

\section{ACKNOWLEDGEMENTS}

We are very grateful to all those who kindly supplied us with material. We gratefully acknowledge the assistance of C. Puch. We also thank Mark Creb who helped us with the 
English translations and Barry W. Brook that reviewed this paper. This study was supported by projects REN2000-2040 GLO, CM 07M/0125/2000 and EVK2-CT-2001-00121 (PASCALIS, European Union).

\section{References}

BragA, M. H., 1949. Un Bathynellacea (Crustacea, Syncarida) du Portugal (Parabathynella lusitanica $\mathrm{n}$. sp.). Publicaçoes do Instituto de Zoologia "Dr. Auguste A. Nobre”, 40: 1-15.

CAMACHO, A. I., 1987. A new subterranean syncarid (Crustacea) from Spain: Iberobathynella imuniensis n.sp. (Bathynellacea, Parabathynelidae). Archiv für Hydrobiologie, 111(1), 137-149.

Camacho, A. I. \& Serban, E., 1998. Tribu des Iberobathynellini nov. Diagnoses des taxa nouveaux (Parabathynellidae, Bathynellacea, Podophallocarida). Travaux de l'Institute de Spéologie Emile Racovitza, [1995], 34: 15-75.

Delamare Deboutteville, C., \& Angelier, E., 1950. Sur un type de crustacé phréaticole nouveau: Parabathynella fagei n. sp. Comptes Rendus du l'Académie des Sciences, Paris, 231: 175-176.

Dennis, B., Munholland, P. L. \& Scott, J. M., 1991. Estimation of growth and extinction parameters for endangered species. Ecological Monographs, 61: 115-143.

Fisher, R. A., Corbet, A. S. \& Williams, C. B., 1943. The relation between the number of species and the number of individuals in a random sample of an animal population. Journal of Animal Ecology, 12: 42-58
Galhano, M. H., 1967. Sur une nouvelle Parabathynella psammique du Portugal. Publicaçoes do Instituto de Zoologia "Dr. Augusto Nobre”, 98: 9-18.

LOMBORG, B., 2001. The Skeptical Environmentalist: Measuring the Real State of the World. Cambridge Univeristy Press. Cambridge. 515 pp.

Margalef, R., 1951. Un sincárido del género Parabathynella en las Baleares. Publicaciones del Instituto de Biología Aplicada, 8: 151-153.

Margalef, R., 1953. Los crustaceos de las aguas continentales Ibéricas. Instituto Forestal de Investigaciones y Experiencias. Madrid. 243 pp.

Morris, W., Doak, D., Groom, M., Kareiva, P., Fieberg, J., Gerber, L., Murphy, P. \& Thomson, D., 1999. A Practical Handbook for Population Viability Analysis. The Nature Conservancy. 79 pp. http://lsweb.la.asu.edu/lgerber/PVA1.pdf

Myers, N., Myers, N. J. \& Simon, J., 1994. Scarcity or Abundance?: A Debate on the Environment. W.W. Norton \& Company. New York. 254 pp.

Pimm, S. \& Harvey, J., 2001. No need to worry about the future. Nature, 414: 149-150.

RacovitzA, E. G., 1907. Essai sur les problèmes biospéologiques. Biospeologica 1, Archives de Zoologie Expérimentale et Générale, 4: 371-488.

Simon, J. L., 1998. The ultimate resource 2. Princeton University Press. Princeton. 778 pp. 